Animal Production and Environment Received on: 23/05/2020

Accepted on: 10/08/2020

\title{
Technological Advances in Cattle Welfare: An Analysis of Patent Families
}

\author{
Avanços Tecnológicos no Bem-Estar de Bovinos: Uma Análise das Famílias de \\ Patentes
}

TEIXEIRA, Odilene de Souza ${ }^{1}$

http://orcid.org/0000-0002-6961-7100

PEREIRA, Lucas Braido ${ }^{2}$

https://orcid.org/0000-0003-3627-724X
FERNANDES, Alice Munz ${ }^{3}$

https://orcid.org/0000-0003-3023-605X

FANTINEL, Antônio Luiz ${ }^{3}$

https://orcid.org/0000-0003-1378-3537

\footnotetext{
${ }^{1}$ Universidade Federal do Rio Grande do Sul, Departamento de Zootecnia, Programa de PósGraduação em Zootecnia, Porto Alegre, RS, Brasil.

${ }^{2}$ Universidade Federal de Santa Maria, Departamento de Zootecnia, Programa de Pós-Graduação em Zootecnia, Santa Maria, RS, Brasil.

${ }^{3}$ Universidade Federal do Rio Grande do Sul, Centro de Estudos e Pesquisas em Agronegócios, Programa de Pós-Graduação em Agronegócios, Porto Alegre, RS, Brasil.

*Corresponding author: odilene_rs@hotmail.com
}

\section{RESUMO}

A pesquisa realizada objetivou analisar o panorama das patentes relacionadas a bem-estar em bovinos. Para tanto, realizou-se uma busca na base mundial de registro de patentes Questel Orbit, orientada para a existência de termos associados ao bem-estar em bovinos nos documentos de famílias de patentes. A investigação correspondeu ao período compreendido desde o início dos registros em 1967 até agosto de 2019. Dessa forma, obteve-se um portfólio inicial composto por 272 registros, e destes, 77 documentos eram concernentes a bovinos, com intervenções diretas ou indiretas na otimização do bemestar. A análise dos dados ocorreu de forma quantitativa e por meio da classificação das famílias de patentes em sete categorias: nutrição, sanidade, manejo, genética, infraestrutura/instalações, indicadores fisiológicos e comportamentais e rastreabilidade/certificação. O maior número de famílias de patentes correspondeu às áreas de instalações rurais, nutrição animal, sanidade e novos indicadores fisiológicos e comportamentais, totalizando $73 \%$. A distribuição temporal desses registros demonstra que o interesse dos pesquisadores quanto à promoção de inovações tecnológicas voltadas ao bem-estar iniciou-se em 1995, com expressividade a partir de 2013. Salienta-se ainda que o maior registro de famílias de patentes advém da China (51\%), seguido dos Países Europeus que, em sua totalidade, respondem por $23 \%$ e pelos Estados Unidos (19\%), ao passo que o Brasil representa apenas $6 \%$ do total dos documentos. Apesar dos recentes registros de patentes relacionados a bovinos, observa-se uma ascensão nos últimos anos, denotando o crescimento dos esforços para inovação tecnológica dessa cadeia produtiva acerca do bem-estar animal. 
Palavras-chaves: Indicadores de bem-estar, Instalações, Nutrição, Prospecção tecnológica

\begin{abstract}
The research carried out intended to analyze the panorama of patents related to welfare in cattle. To this end, a search was carried out on the worldwide Questel Orbit patent registration database oriented toward the existence of terms associated with welfare in cattle in the documents of patent families. The investigation corresponded to the period from the beginning of the registrations in 1967 until August 2019. In this way, an initial portfolio was created of 272 registrations. Of these, 77 documents were related to cattle, with direct or indirect interventions in the optimization of the welfare. Data analysis took place in a quantitative way and through the classification of patent families in seven categories: nutrition, health, management, genetics, infrastructure/facilities, physiological and behavioral indicators, and traceability/certification. The largest number of patent families corresponded to the areas of rural facilities, animal nutrition, health, and new physiological and behavioral indicators, totaling $73 \%$. The temporal distribution of these records shows that the interest of researchers in promoting technological innovations focused on well-being began in 1995, with expressiveness from 2013. It should also be noted that the largest registration of patent families comes from China (51\%), followed by European countries, which account for $23 \%$, and the United States $(19 \%)$, while Brazil represents only $6 \%$ of the total documents. Despite the recent patent registrations related to cattle, there has been an increase in recent years, denoting the growth of efforts for technological innovation of this productive chain regarding animal welfare.
\end{abstract}

Keywords: Facilities, Nutrition, Technological prospecting, Welfare indicators

\section{INTRODUCTION}

The concerns inherent to animal welfare and sustainability have caused transformations in the productive models (Fraser, 2008), which focus on intensified and profitable production in parallel with the minimization of environmental impacts and the promotion of health and welfare (Wathes et al., 2008). In this context, the development of technological innovations focused on precision livestock farming seeks to regularly manage production processes, in counterpoint to the objective verification of animal welfare (Banhazi et al., 2012; Norton \& Berckmans, 2018; Halachmi et al., 2019).
Thus, the contribution of innovations is evidenced as a way of "help accelerate improvement and build upon ongoing work in more efficient and effective ways" including "outside the farm" (Pinillos, 2017). In this sense, technological innovation is configured as an economic and social phenomenon, capable of promoting numerous benefits (Andrade et al., 2017) and causing significant changes in the current sociotechnical systems (Geels, 2004). Therefore, there is a consolidated sequential process from which technological innovation takes place, scientifically known as the Schumpeterian innovation: trilogy invention, innovation, diffusion (Schumpeter, 1936). The invention is 
formally identified through patent registration, officially recognized worldwide as one of the primary indicators of technological innovation in all contexts (e.g., academic, national, business) (OECD, 2005). Therefore, the analysis of patent families is configured as one of the basic indicators of technological progress because it shows the stage of development of a given sector (Vincent et al., 2017; Linhares et al., 2018), presenting information for the different social spheres, such as industry, market, and the public sector (Tseng et al., 2007).

Given the above, the research carried out intended to analyze the panorama of patents related to the welfare of cattle. Thus, it is a study focused on prospecting about the technological advances that are being developed in the area of welfare, with an emphasis on this species. Therefore, it provides an analysis of the geographical and temporal distribution of the origin of these inventions and of the markets in which there is protection for their economic and commercial exploitation (as technological innovations). The classification of these patents into categories and technological domains is also evident, as well as through the pillars of animal production.

\section{METHODOLOGICAL PROCEDURES}

For the operationalization of this research, a search was carried out on the Questel Orbit patent database, which is worldwide in scope and which enables data mining through specific analytical tools (Vincent et al., 2017). This database is configured as an intellectual property portal covering more than 90 offices and patent authorities worldwide (Li, 2018), with daily updates (Questel
Orbit, 2019). For this reason, it can be considered one of the largest patent databases, being a leader in this market (Stock \& Stock, 2005).

The search strategy employed consisted of the following terms, Boolean operators, and truncations: (behavior AND bovine) OR (behavior and beef cattle) OR (behavior AND beef cal+) OR (well-being AND bovine) OR (well-being $A N D$ beef cattle) OR (well-being AND beef cal +) OR (welfare AND bovine) OR (welfare AND beef cattle) OR (welfare AND beef cal+) OR (animal welfare). The existence of these elements was defined in the title and/or summary of the patent documents, and the search period was understood every year from the beginning of the sharing of information (in 1967) until August 20, 2019.

Thus, an initial portfolio was obtained, consisting of 272 records of documents from patent families. A family of patents is understood to be the set of inventions that claim the same priority or combination of priorities, being related to each other. In other words, these derive from a first patent document, the application of which was filed with an international industrial property body (Espacenet, 2020a).

These documents were preliminarily organized through an electronic spreadsheet, considering the diversity of items that integrate and establish standards in the patent registries. These items are called parameters (standardized worldwide), and those analyzed in this study corresponded to the year and country of priority of patent registrations, countries where there is protection from economic and commercial exploitation, technological domains, and International Patent Classification (of the English International Patent Classification- 
IPC).

Both the year and the priority country refer to such variables based on the first patent registration that make up the analyzed family of patents, in which a given priority or combination of priorities is claimed the first time. That is, a patent family is made up of patents that have exactly the same priority or combination of priorities. Therefore, they are patents related to each other based on the priority claimed (Espacenet, 2020a).

The technological domain of patent families concerns the macro area of technology to which they belong. In a similar logic, the content of the documents of the patent families is also uniformly classified based on a globally recognized hierarchical system (IPC). This classification is indicated by means of symbols and indexing codes, which express technological subdivisions that allow one to quickly identify to what the content of a given patent refers (Espacenet, 2020b).

Then, the abstracts and claims of the patent families' documents were carefully read by two researchers and specialists in animal production to identify those that referred only to cattle. Thus, 195 records were excluded because despite meeting the search criteria, they were related to pigs, sheep, chickens, and pets. Therefore, a portfolio was create consisting of 77 documents that addressed cattle welfare, from which the analysis was carried out.

In addition, the portfolio obtained was analyzed, and the patent families were classified into seven aspects directly or indirectly related to the optimization of welfare: i) nutrition; ii) sanity; iii) genetics; iv) management-pillars of animal production-plus v) infrastructure/facilities, vi) physiological and behavioral indicators and, vii) traceability or certification. This classification is in line with the conception defined by Mellor and Reid (1994), who contributed the five domains that can compromise the welfare of animals: i) nutrition (thirst, hunger or malnutrition); ii) environmental challenges; iii) disease (functional impairment); iv) behavior restriction; and v) mental state (e.g., anxiety, fear, pain, anguish). From these parameters, the patent families were classified considering their classification in such pillars.

\section{RESULTS AND DISCUSSION}

In the quest to provide welfare to farm animals, several technological innovations are emerging to manage, control, maintain, evaluate, and promote it (Mancini et al., 2018). These changes will be part of all animal production processes in the coming years (Banhazi et al., 2012). In this sense, from the portfolio obtained in the present research, there is a distribution of patent families on cattle welfare in the seven classification areas (Figure 1), which cover all segments of the production chain, both within the farm and in the slaughterhouse industry to the final consumer. The main area, with the largest number of patent families, corresponds to rural facilities (27\%), which involve technological innovations intended to employ different artifacts in the infrastructure to analyze or manage animal welfare status or even structural changes, promoting well-being. Next, there is animal nutrition (19\%), followed by sanity $(14 \%)$ and new physiological and behavioral indicators (13\%), which add up to $73 \%$ of patent families. 


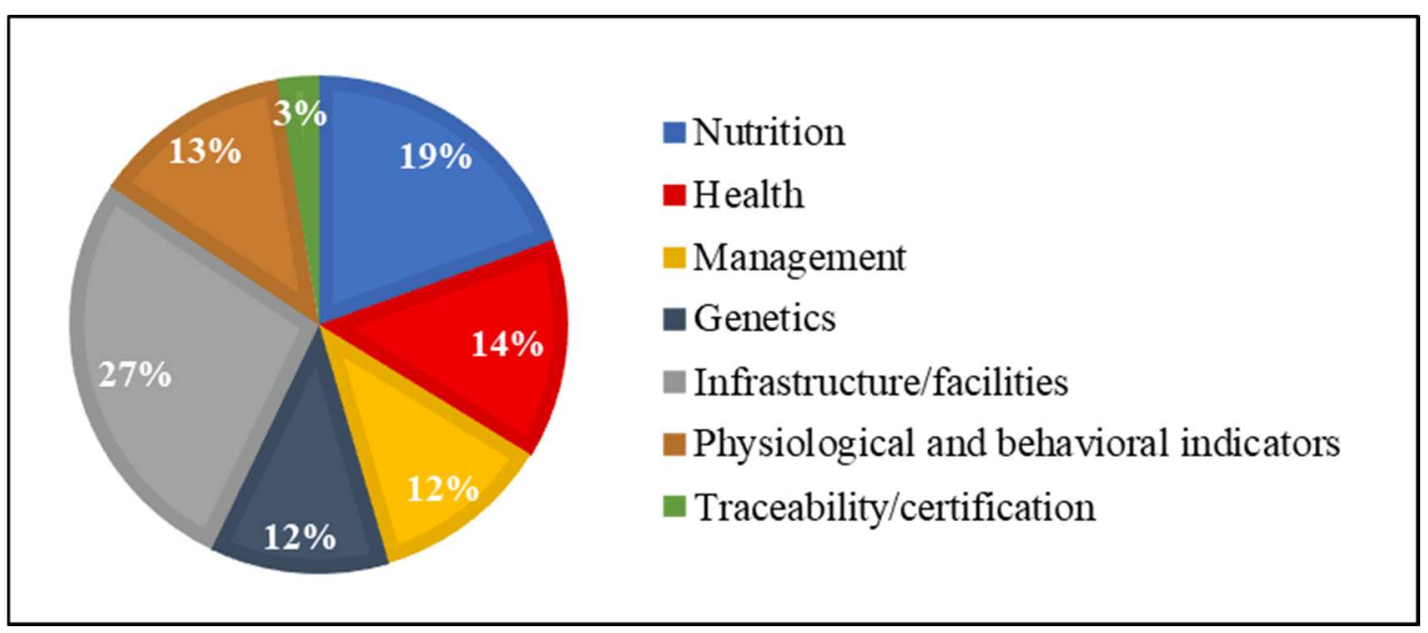

Figure 1. Classification of patent families registrations

Concerning the facilities, it appears that there are novelties in terms of modifications of the animals' containment facilities in the slaughterhouses; changes in the slaughterhouses facilities for religious slaughter; modifications in the facilities for raising calves and in the maritime transport of cattle; insertions of devices to promote the correct luminosity and control of the environment in the installations; transformations in the rest areas of the animals confined; and use of a robotic system for the cleaning and sterilization of the structures, among others.

Regarding nutritional aspects, automatic and real-time food consumption meters stand out, coupled to the animal's neck, new bulky food sources to be used in the feed, different forms of food presentation, new food additives (i.e., flavoring and probiotics), different methods of animal feeding, and automatic systems to control and manage grazing animals, for example. In animal health, pharmaceutical innovations and sound disease detectors are predominantly found. As for the physiological and behavioral indicators, there are the immunological indicators, such as the serum amyloid A protein and the insulin-like growth factor 1, as promising elements in the evaluation of animal welfare. There is also a device that measures the behavior of the animal's judgmental bias, which corresponds to a cognitive assessment technology that can identify positive and negative affective states, as well as new methods of cortisol assessment focused on different stress situations. There are also new ways of indicating the welfare condition during slaughter, for example. Although only $3 \%$ of patent families are involved in the issue of traceability and certification, these are important requirements in the analysis of welfare. According to Banhazi et al. (2012), traceability allows for clarity of information between all links in the production chain, which includes information on how animals were raised, treated, and slaughtered. In this way, it is possible to create public policies and guidelines intended to mitigate or improve inconsistencies between the segments that make up the production chain. Along with traceability, wellbeing certifications stand out, which are 
accepted by consumers, as they consider foods from certified production processes as more suitable for consumption, fostering their credibility and market acceptance (Ufer et al., 2019).

Accordingly, a study on consumption preferences based on human values showed that $87.1 \%$ of Japanese consumers prefer to purchase meat products that present, on their labels, information on animal welfare and environmental practices (Sonoda et al., 2018). This phenomenon, in a way, is related to the search for sustainable production, emphasizing that this system must be acceptable currently and, in the future, especially concerning the availability of natural resources (Broom, 2019).

The temporal distribution of these patent families demonstrates that the interest of researchers on the theme of welfare in cattle has intensified over the years, considering a greater concentration since 2013 (Figure 2). It is also noteworthy that this subject is relatively recent in terms of technological prospecting, with its first patent registered in 1995 in Questel Orbit.

In this sense, animal welfare as a science was developed between 1980 and 1990 (Broom \& Fraser, 2007). Among the seven classifications, it is emphasized that in 2015 there was an intensification of the number of patent families related to the search for physiological and behavioral indicators, as well as those concerning infrastructure/facilities. Specifically, for the facilities, climate change can lead to cold or heat stress in the animals and cause loss of production, which justifies the adjustments in rural buildings, especially for animals with high production rates such as dairy cows (Caja et al., 2016).

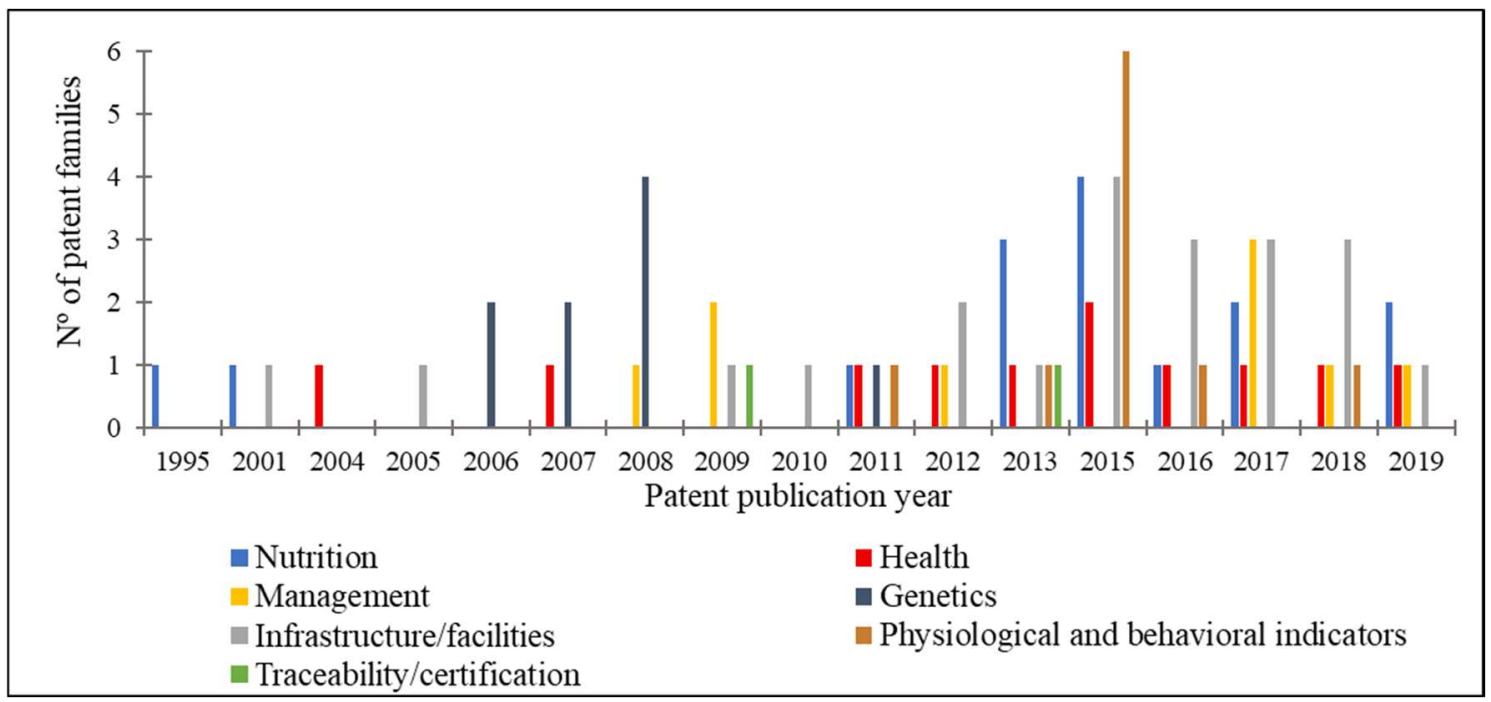

Figure 2. Temporal distribution of patent families registrations

In addition, it is also evident that the segments of the beef or milk production chain are experiencing challenges, as people's lifestyles are changing. Thus, the demands for food are based on moral and ethical issues (Ufer et al., 2019). In this context, researchers have been expending efforts to understand the perceptions of individuals concerning animal welfare (Evans \& Miele, 2019). 
Nevertheless, the new technologies created are oriented to undergo a bioethical analysis, based on studies and evaluations by moral judges, to make the production system transparent to society (Wathes et al., 2008).

In this regard, the European project called Dairy Care, lasted four years (2014-2018) and was formed by a network of wellness experts and scientists from different fields of knowledge (e.g., computing, systems, economics). The primary objective of this project was the development and application of new technological solutions to improve the welfare of the dairy industry. The outcome resulted in the creation of welfare biomarkers, in which ideal production conditions for animals were prioritized, improvement valuation and product quality, impacting the maximization of consumer confidence. In the joint analysis of patent family registrations, regardless of classification, China stands out as the main priority country (where the registration of a patent family was required first), representing $51 \%$ of the total patent family registrations (Figure $3)$. In this sense, it is emphasized that "the Chinese government has used a number of policies to encourage commercial agribusiness firms to do more research and innovation" (Jin et al., 2017). As a consequence, as of 2011, the country appears as a world leader in patent filing, which is justified, above all, by the high investment in research and development (Chen \& Zhang, 2019). In addition to China, European countries, together, account for $23 \%$ of patent families, followed by the United States, which contributes $19 \%$, while Brazil represents only $6 \%$, as does the Republic of Korea. In this sense, Norton and Berckmans (2018) observe the advances in precision livestock technologies globally, with events occurring mainly in Europe, the United States, and China. Specifically, in China, in 2016, the first Asian conference on precision livestock was held (First Asian Conference on Precision Livestock Farming), denoting the country's updating concerning this theme. 


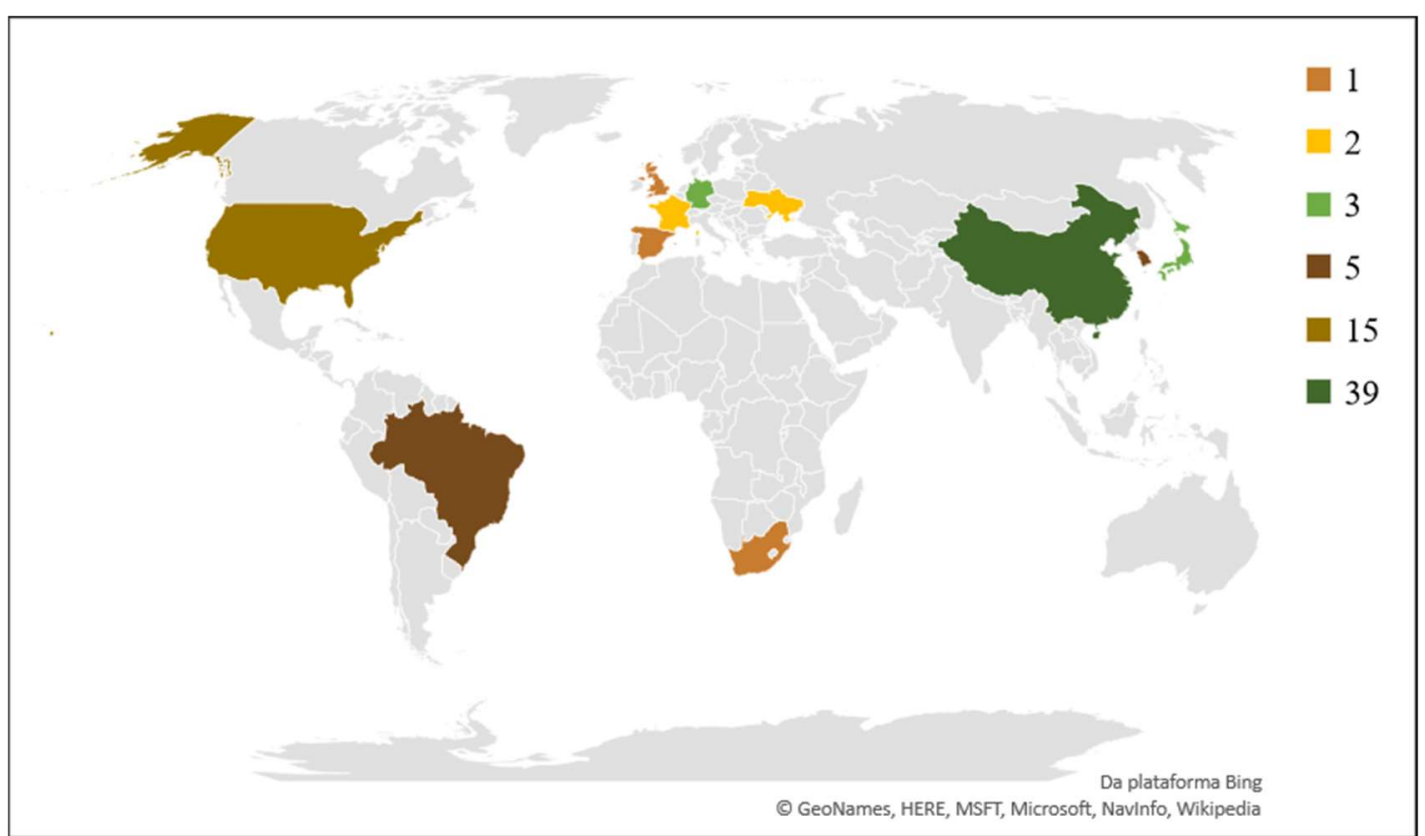

Figure 3. Priority countries of the patent families registrations analyzed

However, inventions can be economically and commercially protected through the registration of patents in more than one country or a worldwide body. Thus, the analyzed patents total 147 protections, distributed in 3 world organizations (the World Intellectual Property Organization, European Patent Organization, and Eurasian Patent Organization) and 18 countries. Thus, China also stands out as the territory with the highest number of protections (43 patents), followed by the United States (18 patents) and the World Intellectual Property Organization (17 patents) via the Patent Cooperation
Treaty-PCT) that makes it possible to simultaneously seek protection for an invention in a large number of countries that have joined the treaty (Wipo, 2019). Nevertheless, occupying the fourth place in this ranking is Brazil, where 11 patents were protected.

Concerning the classification of technologies, it appears that the analyzed patent families fall into 17 different technological domains (Figure 4), with emphasis on the group related to other special machines that include 40 documents from patent families, followed by biotechnology and food chemistry, with 13 records each. 


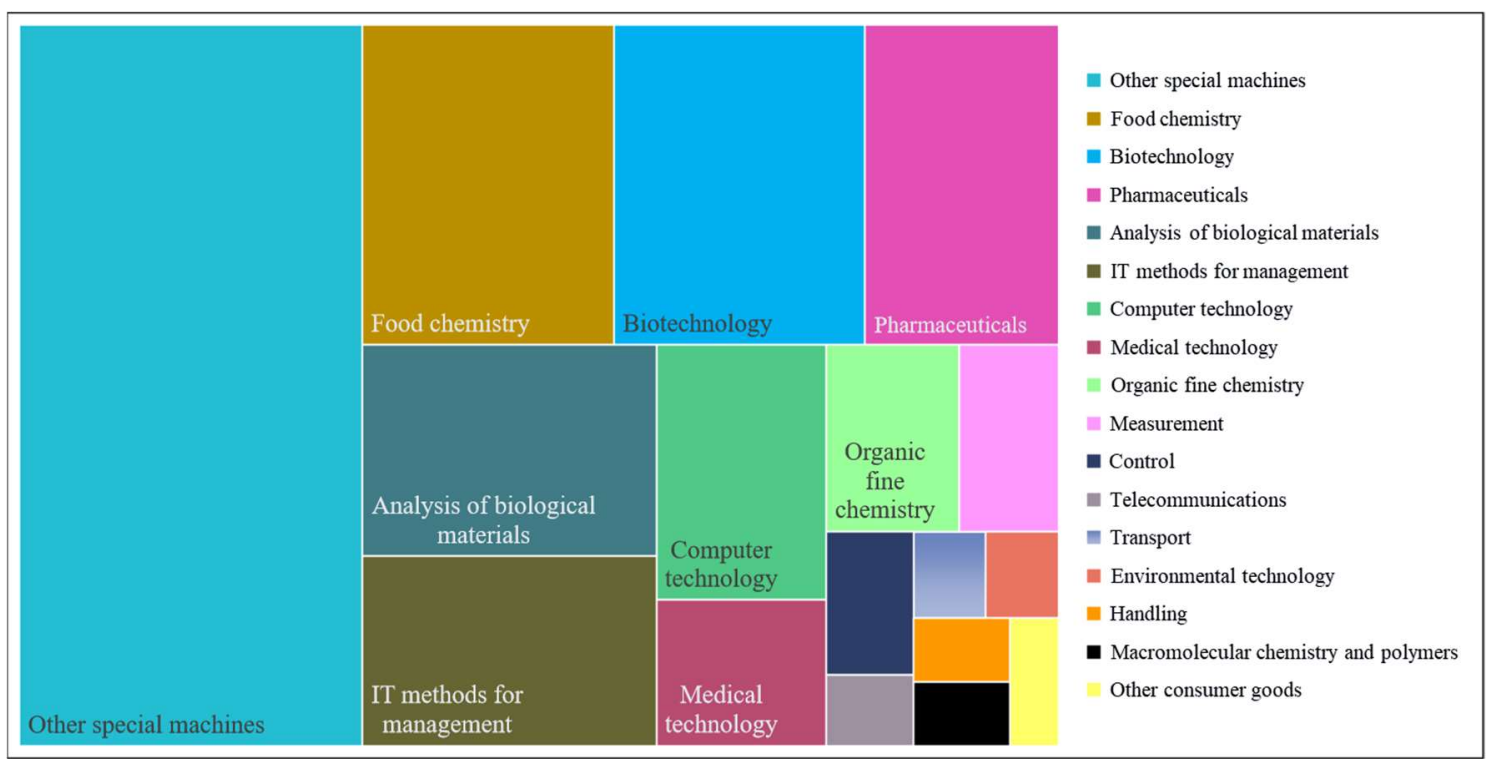

Figure 4. Technological domains of the patent families registrations analyzed

To stratify technological issues, we proceeded with the verification of the classifications of patent families on welfare in cattle, according to the IPC. Thus, it appears that these documents have 164 different classifications that belong to 37 subsections (Figure 5). Among these, Section A stands out, which refers to human needs with emphasis mainly on subsections $\mathrm{A} 01 \mathrm{~K}$ (livestock; treatment of birds, fish, insects; fish farming; breeding or reproduction of animals, not included elsewhere; new animal creations) with 42 records and A23K (food products specially adapted for animals; methods specially adapted for their production), which accounts for 40 records.

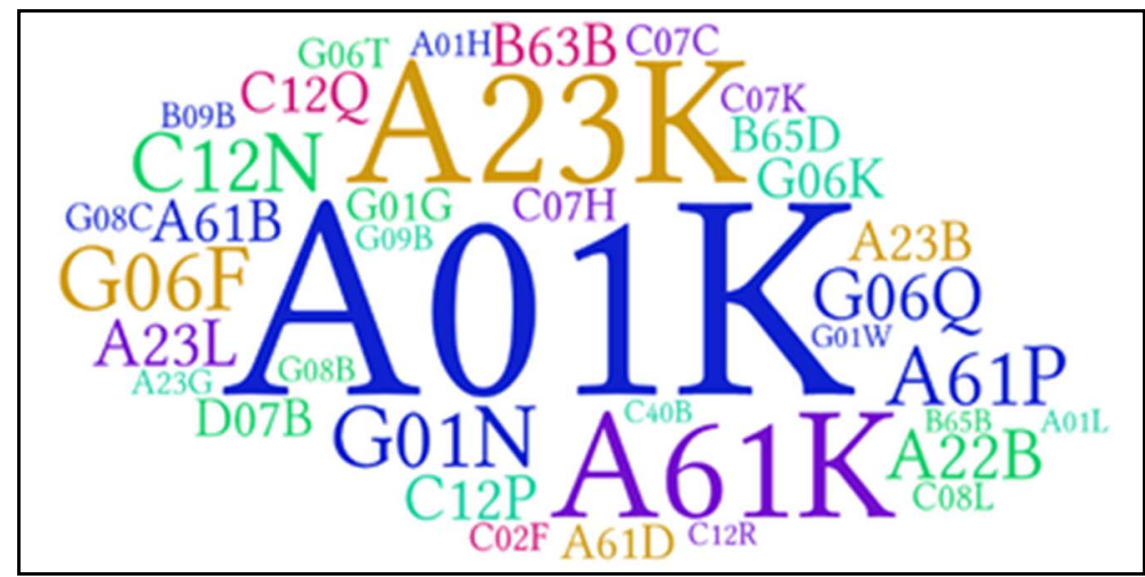

Figure 5. IPC classification of the patent families registrations analyzed

Given the above, it appears that the welfare of cattle is configured as an area with technological expansion bias, the emerging development of which reflects signs of maximizing the concerns of society and the search for the improvement of production processes throughout the animal production chain. 
This expressiveness of new technologies is due to the technological progress of engineering and the possibility of creating efficient sensors that are increasingly less expensive (Caja et al., 2016).

However, it is not enough that there are inventions. They need to be developed and exploited economically. It is also necessary that they are known, accessed, and implemented by rural producers, slaughterhouses, and other agents involved (Grandin, 2010). In this regard, there is still a need to evolve in the clear presentation of the benefits of using these technologies to the rural manager, at the same time that integrated models of monitoring and management of welfare must be considered (Wathes et al., 2008; Banhazi et al., 2012).

Nevertheless, it is recognized that the lack of clarity in the writing of documents from patent families and the use, generally intentional, of a variety of terminologies to refer to the same subject, despite being configured as common characteristics of this type of registry (Judea et al., 2014), may have limited the search and neglected to include other documents. Therefore, even if the analyzed database is endowed with relevance, it cannot be guaranteed that its entire universe of records has been compiled in the obtained portfolio.

\section{FINAL CONSIDERATIONS}

The registration of patent families related to cattle farming is on the rise, with intensification in technological innovations in the area of installation, health, nutrition, and physiological and behavioral indicators both inside and outside the farm. In view of this, there is the possibility of improving conditions for production animals and meeting the population's demands for products that demonstrate their ethical and moral concern, with respect and animal zeal, in conjunction with the promotion of safety and food safety.

Patent families related to animal welfare originated in 1995 and were highlighted in the registration number in 2013, with China, the group of European countries, and the United States leading the world ranking in the number of patent registrations. Among the patent families, the primary classification is found in special machines. According to the IPC classification, patent families refer predominantly to human needs.

Therefore, from this world panorama on patent families, it is observed that animal welfare is at the heart of techno-scientific efforts to promote innovations and improve production systems. Thus, it is usually a matter of time before the advances in research and development, expressed by means of patents for invention, materialize in disruptive technologies capable of causing significant transformations in the production of cattle, which shows that it is increasingly oriented and concerned with animal welfare.

However, the limitations of the study regarding the search in a single database are recognized, which, despite being significant and with a worldwide scope, does not include all existing patent documents. For future studies, it is recommended to analyze the companies and possible startups that developed or financed the analyzed innovations to verify the state of the art of the technology regarding animal welfare. A detailed analysis is also suggested on the possible impact of the application of those patented technologies that are not yet commercially exploited, which may demonstrate the potential changes 
oriented to the welfare of cattle production systems in a future that tends to be close.

\section{REFERENCES}

ANDRADE, H. S.; CHAGAS JR., M. F.; SILVA, M. B.; CHIMENDES, C. G.; ROSA, A. C. M. Proposal for the application of Technological Prospecting approach to a Scientific and Technological Institution.

International Journal of Humanities and Social Science Invention, v. 6, n. 10, p. 61-67, 2017.

BANHAZI, T. M.; LEHR, H.; BLACK, J. L.; CRABTREE, H.; SCHOFIELD P.; TSCHARKE, M.; BERCKMANS, D. Precision Livestock Farming: An international review of scientific and commercial aspects. International Journal of Agricultural and Biological Engineering., v. 5, p. 1-9, 2012.

BROOM, D. M. Animal welfare complementing or conflicting with other sustainability issues. Applied Animal

Behavior Science, v. 219, p. 104829, 2019.

BROOM, D. M.; FRASER, A. F. Domestic Animal Behaviour and Welfare. Oxford: Oxford University Press, 2007.

CAJA, G.; CASTRO-COSTA, A.; KNIGHT, C. H. Engineering to support wellbeing of dairy animals. Journal of Dairy Research, v. 83, p. 136-147, 2016.

CHEN, Z.; ZHANG, J. Types of patents and driving forces behind the patent growth in China. Economic Modelling, v. 80, p. 294-302, 2019.

\section{DairyCare. European Commission} COST Action FA1308. 2016.

Available in: < http://www.cost.eu/costaction/dairycare//>. Acess in: 03 July 2020 .

ESPACENET. Patent search: a service provided in co-operation with the EPO. Patent families. 2020a.

Available in:

$<$ https://lp.espacenet.com/help?locale=e n_LP\&method=handleHelpTopic\&topic $=$ patentfamily $>$. Acess in: 09 July 2020 .

\section{ESPACENET. Patent search: a} service provided in co-operation with the EPO. International Patent

Classification (IPC) system. 2020b.

Available in:

$<$ https://lp.espacenet.com/help?locale=e n_LP\&method=handleHelpTopic\&topic $=$ ipc $>$. Acess in: 09 jul. 2020.

EVANS, A.; MIELE, M. Enacting public understandings: The case of farm animal welfare. Geoforum, v. 99, p. 110, 2019.

FRASER, D. Animal welfare and the intensification of animal production. In: THOMPSON, P. B. (Ed.). The ethics of intensification. Dordrecht: Springer, 2008. p. 167-189.

GEELS, F. W. From sectoral systems of innovation to socio-technical systems: insights about dynamics and change from sociology and institutional theory. 
Research Policy, v. 33, p. 897-920, 2004.

GRANDIN, T. Implementing effective standards and scoring systems for assessing animal welfare on farms and slaughter plants. In: GRANDIN, T. (Ed.). Improving animal welfare: a practical approach. Cambridge: $\mathrm{CAB}$ International, 2010.

HALACHMI, I.; GUARINO, M.; BEWLEY, J.; PATELL, M. Smart animal agriculture: application of realtime sensors to improve animal wellbeing and production. Annual Review of Animal Biosciences, v. 7, p. 403425, 2019.

JIN, Y.; HU, Y.; PRAY, C.; HU, R. Impact of government science and technologies policies with a focus on biotechnology research on commercial agricultural innovation in China. China Agricultural Economic Review, v. 9, n. 3, p. 438-452, 2017.

JUDEA, A.; SCHÜTZE, H.; BRÜGMANN, S. Unsupervised training set generation for automatic acquisition of technical terminology in patents. In: Proceedings of Coling 2014, the 25th International Conference on Computational Linguistics: Technical Papers. 2014. p. 290-300.

LI, N. International patent analysis of water source heat pump based on Orbit Database. In: IOP Conference. Series: Earth and Environmental Science, v. 121, p. 1-6, 2018.

LINHARES, A. M. F.; GRANDO, R. M. L.; BORGES, C. P.; FONSECA. F. $\mathrm{V}$. Technological prospection on membranes containing silver nanoparticles for water disinfection.

Recent Patents on Nanotechnology, v. 12, p. 3-12, 2018.

MANCINI, M. C.; MENOZZI, D.; ARFINI, F.; VENEZIANI, M. How Do Firms Use Consumer Science to Target Consumer Communication? The Case of Animal Welfare. In: CAVICCHI, A.; SANTINI, C. (Eds). Case Studies in the Traditional Food Sector. Italy: Woodhead Publishing, 2018. p. 337357.

MELLOR, D. J.; REID, C. S. W. Concepts of animal well-being and predicting the impact of procedures on experimental animals. In: Improving the Well-Being of Animals in the Research Environment; Australian and New Zealand Council for the Care of Animals in Research and Teaching: Glen Osmond, Australia, 1994. p. 3-18.

NORTON, T.; BERCKMANS, D. Engineering advances in Precision Livestock Farming. Biosystems Engineering, v. 173, p. 1-3, 2018.

OECD. Oslo Manual: guidelines for collecting and interpreting innovation data. 3. ed. Paris: OECD EUROSTAT, 2005.

PINILLOS, R. G. Precision slaughter: improve welfare at slaughter and killing through technological innovation.

Precision Livestock Farming 2017 Papers Presented at the 8th European Conference on Precision Livestock Farming, p. 550-556, 2017.

QUESTEL ORBIT. Orbit Intelligence. 2019. Available in: < 
https://www.questel.com/ip-businessintelligence-software/orbit-

intelligence/>. Access in: 28 Aug. 2019.

SONODA, Y.; OISHI, K.; CHOMEI, Y.; HIROOKA, H. How do human values influence the beef preferences of consumer segments regarding animal welfare and environmentally friendly production? Meat Science, v. 146, p. 75-86, 2018.

SCHUMPETER, J. A. The theory of economic development. 2. ed.

Cambridge: Harvard University Press, 1936.

STOCK, M.; STOCK, W. G.

Intellectual property information. A case study of Questel-Orbit.

Information Services \& Use, v. 25, n. 3-4, p. 163-180, 2005.

TSENG, Y.H.; LIN, C. J.; LIN, Y. I. Text mining techniques for patent analysis. Information Processing \&

Management, v. 43, n. 5, p. 1216-1247, 2007.
UFER, D.; ORTEGA, D. L.; WOLF, C.A. Economic foundations for the use of biotechnology to improve farm animal welfare. Trends in Food Science \& Technology, v. 91, p. 129138, 2019.

VINCENT, C. L.; SINGH, V.; CHAKRABORTY, K.;

GOPALAKRISHNAN, A. Patent data mining in fisheries sector: an analysis using Questel-Orbit and Espacenet.

World Patent Information, v. 51, p. 22-30, 2017.

WATHES C. M.; KRISTENSEN, H. H.; AERTS, J. M.; BERCKMANS, D. Is precision livestock farming an engineer's daydream or nightmare, an animal's friend or foe, and a farmer's panacea or pitfall? Computers and Electronics in Agriculture, v. 64, p. 210, 2008.

WIPO. Word Intellectual Property Organization. PCT: The International Patent System. 2019. Available in: < https://www.wipo.int/pct/en/>. Acess in: 12 Sep. 2019. 